\title{
Indoor Navigation System for Visually Impaired using Real Time 3D Depth Sensing Sensor
}

\author{
Reo J Mathew ${ }^{1}$, Harilekshmi D Panicker ${ }^{2}$, Akzeeb Bose ${ }^{3}$, Ms.Divya S B ${ }^{4}$ \\ ${ }^{1}$ Student, Dept. of Computer Science\& Engineering, Mangalam College of Engineering, India, \\ reojmathew@gmail.com \\ ${ }^{2}$ Student, Dept. of Computer Science\& Engineering, Mangalam College of Engineering, India, \\ akzeebose@gmail.com \\ ${ }^{3}$ Student, Dept. of Computer Science\& Engineering, Mangalam College of Engineering, India, \\ lekshmih3@gmail.com \\ ${ }^{4}$ Assistant Professor, Dept. of Computer Science\& Engineering, Mangalam College of Engineering, India, \\ divya.sb@mangalam.in
}

\begin{abstract}
This paper portrays a novel idea for aiding the visually impaired individuals to navigate indoors freely without depending on anyone but only by using a Smartphone. The system has been developed in such a way that it is feasible on any android device, having a depth sensing image sensor.

The application makes use of an Indoor Positioning System (IPS), that can use different types of sensory information to locate objects or people inside a large complex.
\end{abstract}

Navigating indoors is the most challenging. It is purely an application for the android Smartphone which uses Augmented reality (AR) and the visually impaired obtains navigation instructions in the form of audio. This can help provide step by step walking independently.The proposed system works with AR Core by Google, with the help of unity engine to process the images in augmented reality to detect the obstacles while navigating indoor and sends an audio message to the user to help him/her to navigate.

Key words: AR Core, Image Processing, Unity Engine

\section{INTRODUCTION}

Image processing is a method to perform some operations on an image in order to extract some useful information's from it. Image processing on mobile devices has grown significantly over the past decade. This resulted in various technology like augmented technology, virtual reality object recognition and so on. Virtual reality is a $3 \mathrm{~d}$ computer generated environment which can be explored to interact with a person or object [5]. Virtual reality headsets have restored sight to people who are blind. Augmented reality is also a computer-generated image on the user's view of the real world.[6]Machine learning is a field of study that gives the computer ability to learn without being explicitly learned. It provides the system the ability to learn from the experience. Most of the devices for the visually impaired uses computer vision and machine learning.[9] The machine learning and audio cues combination improves the lives of visually impaired people (Figure 2).

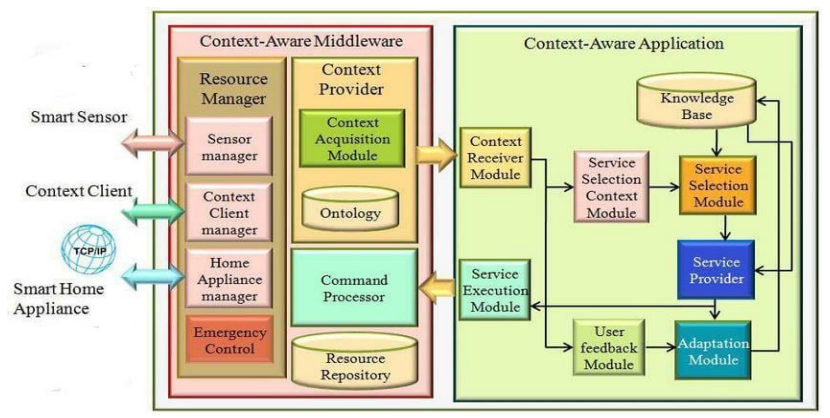

Figure 1: Application 


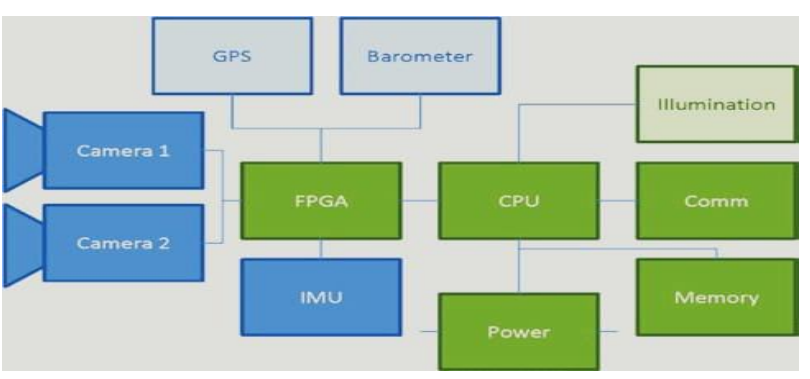

Figure 2: Image Processing

\section{MOTIVATION}

We all have seen and heard of struggles faced by visually impaired. We have nothing but sympathy towards them. They all wish to be independent and don't crave sympathy from others. They work and strive hard to lead a life independently [4]. They always need to search and put much effort to get everyday objects so this device is developed for such people and improve their daily chores without the aid of anyone else.[7]

\section{LITERATURE SURVEY}

In Table 1 we are comparing NSVI with other existing techniques to produce the best.

Table 1: Literature Review

\begin{tabular}{|c|c|c|c|c|}
\hline Sl no. & \begin{tabular}{|l|} 
Title \\
\end{tabular} & Key Concept & Merits & \begin{tabular}{|l|} 
Demerits \\
\end{tabular} \\
\hline 1 & $\begin{array}{l}\text { HOW DOES VISUAL } \\
\text { IMPAIRMENT } \\
\text { AFFECT } \\
\text { PERFORMANCE ON } \\
\text { TASKS OF } \\
\text { EVERYDAY LIFE? }\end{array}$ & $\begin{array}{l}\text { Visual acuity, } \\
\text { contrast sensitivity, } \\
\text { Performance was } \\
\text { assessed } \\
\text { on mobility, daily } \\
\text { activities with a } \\
\text { strong visual } \\
\text { Component, and } \\
\text { visually intensive } \\
\text { tasks. }\end{array}$ & $\begin{array}{l}\text { Both contrast } \\
\text { sensitivity and visual } \\
\text { acuity loss contribute } \\
\text { independently to } \\
\text { deficits in } \\
\text { performance on } \\
\text { everyday tasks. It is } \\
\text { possible to identify } \\
\text { visual acuity and } \\
\text { contrast loss where } \\
\text { most are digabled. }\end{array}$ & $\begin{array}{l}\text { the cutoff points } \\
\text { depend on the } \\
\text { task, suggesting } \\
\text { that defining } \\
\text { disability using a } \\
\text { gingle threshold } \\
\text { for visual acuity } \\
\text { or contrast } \\
\text { gensitivity logs is } \\
\text { arbitrary. }\end{array}$ \\
\hline 2 & \begin{tabular}{|l|} 
SELF-REPORTS OF \\
PHYCHOLOGICAL \\
DISTRESS IN \\
CONNECTION WITH \\
VARIOUS DEGREES \\
OF VISUAL \\
IMPAIRMENT. \\
\end{tabular} & $\begin{array}{l}\text { Visual Impairment, } \\
\text { Intrusive thoughts, } \\
\text { health, }\end{array}$ & $\begin{array}{l}\text { This was one of the } \\
\text { first ever surveys } \\
\text { which helped to } \\
\text { understand the mental } \\
\text { gtate of VI persons }\end{array}$ & $\begin{array}{l}\text { Since it is based } \\
\text { on survey, the } \\
\text { calculations are } \\
\text { only nearly } \\
\text { perfect. }\end{array}$ \\
\hline 3 & $\begin{array}{l}\text { A SPOT REMINDER } \\
\text { SYSTEM FOR THE } \\
\text { VISUALLY } \\
\text { IMPAIRED BASED ON } \\
\text { A SMARTPHONE } \\
\text { CAMERA }\end{array}$ & $\begin{array}{l}\text { spot reminder; } \\
\text { visually impaired } \\
\text { individuals; } \\
\text { gmartphone } \\
\text { cameras; scale } \\
\text { invariant } \\
\text { feature transform; } \\
\text { image matching; } \\
\text { user study }\end{array}$ & $\begin{array}{l}\text { Proposed a spot } \\
\text { reminder system to } \\
\text { assist visually } \\
\text { impaired users in } \\
\text { recalling memories } \\
\text { related to spots that } \\
\text { they visited. }\end{array}$ & $-\cdots$ \\
\hline 4 & \begin{tabular}{|l} 
OBSTACLE \\
DETECTION AND \\
WARNING SYSTEM \\
FOR VISUALLY \\
IMPAIRED PEOPLE \\
BASED ON \\
ELECTRODE MATRIX \\
AND MOBILE \\
KINECT. \\
\end{tabular} & $\begin{array}{l}\text { Mobile Kinect - } \\
\text { Obstacle detection - } \\
\text { Point cloud } \\
\text { Assistive system for } \\
\text { visually impaired }\end{array}$ & $\begin{array}{l}\text { It is proved that } \\
\text { people can be trained } \\
\text { to adapt to a new } \\
\text { gense to recover lost } \\
\text { information due to } \\
\text { impaired sensory } \\
\text { modality. }\end{array}$ & $\begin{array}{l}\text { Not all users can } \\
\text { totally get used to } \\
\text { this kind of device } \\
\text { and the mobility } \\
\text { still depends } \\
\text { mainly on their } \\
\text { natural feeling and } \\
\text { instinct. }\end{array}$ \\
\hline 5 & $\begin{array}{l}\text { VISUAL AND IR } \\
\text { SENSOR DATA- } \\
\text { BASED OBSTACLE } \\
\text { DETECTION FOR THE } \\
\text { VI USING THE } \\
\text { GOOGLE PROJECT } \\
\text { TANGO TABLET } \\
\text { DEVELOPMENT KIT } \\
\text { AND THE UNIYY } \\
\text { ENGINE. }\end{array}$ & $\begin{array}{l}\text { Visually impaired, } \\
\text { blind, obstacle } \\
\text { detection, obstacle } \\
\text { avoidance, } \\
\text { navigation, Unity, } \\
\text { Project } \\
\text { Tango, assigtive } \\
\text { technologies, } \\
\text { multimodal gensors. }\end{array}$ & $\begin{array}{l}\text { A novel visual and } \\
\text { infrared sensor data- } \\
\text { based application } \\
\text { to assist VI users in } \\
\text { detecting and } \\
\text { avoiding obstacles in } \\
\text { their path while } \\
\text { independently } \\
\text { navigating indoors }\end{array}$ & $\begin{array}{l}\text { Needs to improve } \\
\text { functionality and } \\
\text { usability. } \\
\text { User Interface } \\
\text { need to be } \\
\text { friendlier. }\end{array}$ \\
\hline
\end{tabular}

\section{PROPOSED APPROACH}

We name the proposed navigation system "AIDEZ" which enables users to navigate independently with the aid of an android Smartphone which uses machine learning to analyze fed data from cameras and sensors. The obstacles guide is given in the form of audio [3].

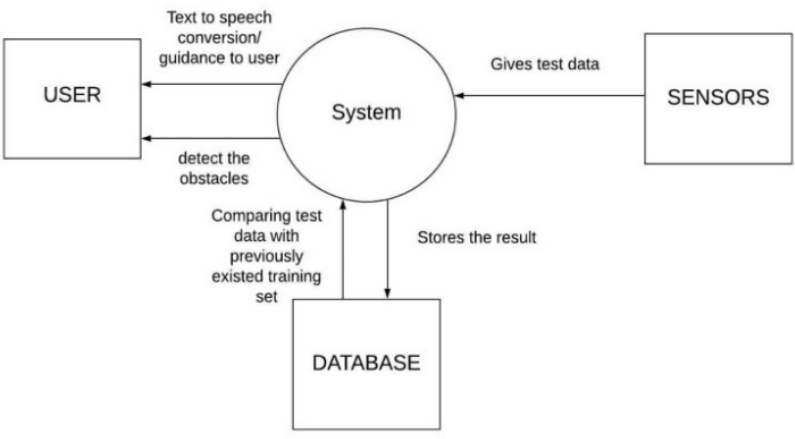

Figure 3: Block Diagram of System

In Figure 3 the app uses AR Core technology to produce the 3D depth image of the space it points to. It produces a depth image of the surroundings and if it finds any potential threat of collision, it informs the user that there is an obstacle ahead and would instruct to change the direction so as to avoid the obstacle [2]. AR Core is a project from Google which helps to visualize things in augmented reality. The images thus obtained are converted to $3 \mathrm{D}$ and collision course are measured.[8] The information is then passed to a database which analyses the image obtained to find out obstacles. It then converts it to an audible warning which warns the user through the headset[1].

The database stores the obtained results and data that would help in future to develop a modified version of this project. The future versions may include a dedicated application that runs on any platform, which provides the same experience for the user as this tablet does.[10] Its merits are helping to reduce accidents, works without internet and cost effective. 
Reo J Mathew et al., International Journal of Computing, Communications and Networking, 9(2) April - June 2020, 21 - 24

\section{TEST CASES}

Table 2: Test Cases

\begin{tabular}{|l|l|l|l|l|}
\hline Test Id & Tested & Expected Result & Actual Result & Successful \\
\hline 1 & User Interface & Opening the APP & $\begin{array}{l}\text { App opens } \\
\text { showing the } \\
\text { desired interface }\end{array}$ & Successful \\
\hline 2 & Detecting & $\begin{array}{l}\text { Detecting using } \\
\text { camera }\end{array}$ & $\begin{array}{l}\text { Camera detects } \\
\text { each and every } \\
\text { object }\end{array}$ & Successful \\
\hline 3 & $\begin{array}{l}\text { Calculating } \\
\text { distance }\end{array}$ & $\begin{array}{l}\text { Using image } \\
\text { processing }\end{array}$ & $\begin{array}{l}\text { Using image } \\
\text { processing it } \\
\text { calculates } \\
\text { distance for } \\
\text { providing path }\end{array}$ & Successful \\
\hline
\end{tabular}

In table2., we have several test cases like the basic usage of our app as initial stage then from that camera will use image processing techniques to calculate the distance of each object and gives the desired path for visual impaired (Figure4).

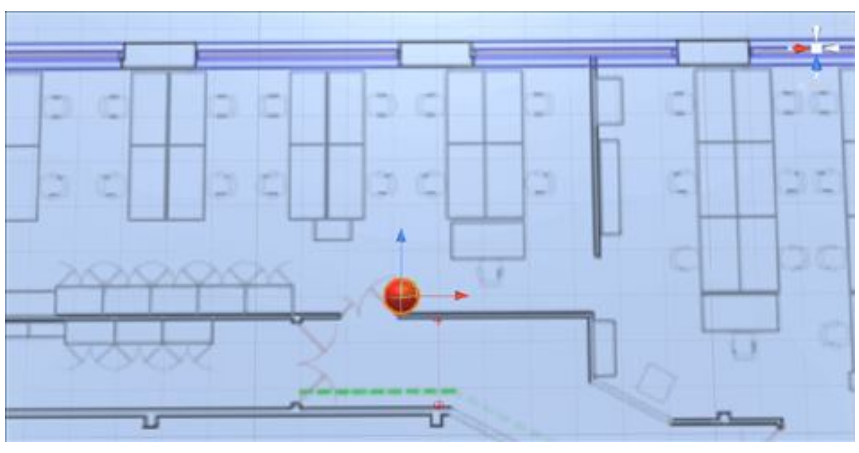

Figure 4: Output of System

\section{CONCLUSION AND FUTURE SCOPE}

Visual and infrared sensor data-based application to assist VI users in detecting and avoiding obstacles in their path while independently navigating indoors.Providing VI users with a real-time mobile assistive stand-alone application on a cutting-edge device which allows them to detect obstacles independently in possibly unfamiliar indoor surroundings would stingingly increase their autonomy.

In future iterations of the system, we plan to enable the area learning option provided in the Unity Tango SDK which would allow the system to remember where static obstacles in the environment are located. Provide a sensation of vision for the visually impaired people by projecting the image directly to cornea of eye. We also plan to develop an independent application that can run on any platform so people can access from anywhere.

\section{ACKNOWLEDGEMENT}

We take this opportunity to express our sincere gratitude to all respected personalities who had guided and helped us in the completion of this paper. First, we express our thanks to Almighty God for guiding us in this venture and make it a huge success. We also thank the management of Mangalam College of Engineering, and Principal for permitting us to carry out this paper. Our sincere thanks to Head of Department of Computer Science and Engineering for permitting us to make use of facilities available in the department. Finally, we extend our gratefulness to all teaching and non-teaching staffs who were involved in this successful completion of this paper work and to all our friends who have patiently extended all sorts of help for accomplishing this paper.

\section{REFERENCES}

[1] R. Manduchi and S. Kurniawan, “Mobility-related accidents experienced by people with visual impairment," AER J., Res. Pract. Vis. Impairment Blindness, vol. 4, no. 2, pp. 4454, 2011.

[2] S. K. West, “'How does visual impairment affect performance on tasks of everyday life? The SEE project," Evidence-Based Eye Care, vol. 3, no. 4,pp. 218219, 2002.

[3] J. S. Karlsson, 'Self-reports of psychological distress in connection with various degrees of visual impairment," J. Vis. Impairment Blindness, vol. 92, pp. 483490, Jul. 1998.

[4] M. Wilson. (2015). 'Who Put That There!': The Barriers to Blind Partially Sighted People Getting Out About. Accessed, Vol 9, April 2017. 
[5] S. Shoval, I. Ulrich, and J. Borenstein, “NavBelt and the guide-cane[obstacle-avoidance systems for the blind and visually impaired]," IEEER obot. Autom. Mag., vol. 10, no. 1, pp.920, Mar. 2003.

[6] H. Liu, J. Wang, X. Wang, and Y. Qian, “iSee: Obstacle detection and feedback system for the blind," in Proc. ACM Int. Joint Conf. Pervas. Ubiquitous Comput., Osaka, Japan, 2015, pp. 197200.

[7] S. Wang and Y. Tian, “Detecting stairs and pedestrian crosswalks for the blind by RGBD camera," in Proc. IEEE Int. Conf. Bioinform. Biomed. Workshops (BIBMW), Oct. 2012, pp. 732739.

[8] D. M. Zuckerman, Blind Adults in America: Their Lives and Challenges.Washington, DC, USA: National Center for Policy Research for Women \&Families, 2004.

[9] M.-C. Kang, S.-H. Chae, J.-Y. Sun, J.-W.Yoo, and S.-J.Ko, “A novel obstacle detection method based on deformable grid for the visually impaired,"IEEE Trans. Consum. Electron., vol. 61, no. 3, pp. 376383, Aug. 2015.

[10] B. Mustapha, A. Zayegh, and R. K. Begg, "Wireless obstacle detection system for $t$ he elderly and visually impaired people," in Proc. IEEE Int.Conf. Smart Instrum., Meas. Appl. (ICSIMA), Nov. 2013, pp. 15. 